\title{
Adaptation Perspective in Implementing Physical Education in Schools
}

\author{
Munira Mohsin", PhD \\ Institute of Teacher Education, Kuala Lumpur, Malaysia
}

*Corresponding Author: Munira Mohsin, Institute of Teacher Education, Kuala Lumpur, Malaysia

\begin{abstract}
This qualitative study is aimed at describing the implementation of the Malaysian Physical Education school curriculum in Form One in schools. The focus of the study is on the role of teachers in implementing the curriculum according to what is planned (fidelity perspective) and the factors influencing the teachers in adapting the curriculum (adaptation perspective). Respondents were two teachers who taught in the vicinity of the Klang Valley. Data were gathered through interviews with the teachers, observations of teaching and learning over seven months, and related curriculum documents. Findings showed that although teachers outwardly, that is, in their lesson planning book implemented according to the curriculum documents, in practice what actually transpired in the Physical Education class was the opposite. In other words, the formal or written curriculum differed from the implemented curriculum experienced by the students. This gap in implementation depended on factors such as interest, requirements and needs, and gender of student, infrastructure and facilities available, as well as the teacher's conceptions regarding the importance of Physical Education and their role related to it. Hence, it can be concluded that Physical Education teachers have wide scope to adapt the curriculum because the status of the curriculum is not examined. The findings give the implication that curriculum planning of Physical Education must take into account the unique characteristics of the subject because only by doing so can the pure objectives of the curriculum be achived, namely the aim of ensuring students attain fitness through physical activity and practising good habits.
\end{abstract}

Keywords: Physical Education, Adaptation Percpective

\section{INTRODUCION}

Education curriculum is a program that constantly changes and develops in line the advancement of society and nation. Development and curriculum change does not happen by itself but is caused by factors that will lead to positive effects (Fullan, 2001). Curriculum development and change is indeed necessary because the community, students, resources and innovation inn teaching are changing from time to time (Marsh \& Willis, 2007). The subject curriculum is formulated based on a philosophy and formation of appropriate curriculum whether in the aspect of idealism, realism, naturalism, pragmatism and existentialism (Annarino, Cowell, \& Hazelton, 1980; Kelly \& Melograno, 2004), aimed at tapping the potential of students from three domains of learning.

In Malaysia, the curriculum in schools is based on the goals and philosophy of education (Abu Bakar Nordin \& Ikhsan Othman, 2003; Sharifah Maimunah Syed Zin, 2007). One of the mandatory curriculum to be studied by all pupils in the primary, lower secondary and upper secondary education system in Malaysia is the curriculum in Physical Education (Education Act, 1996). The Physical Education curriculum has changed since it was first introduced in 1910. Initially the Physical Education curriculum emphasized the concept of gymnastics with focus on elements of strength, flexibility and agility; it then focused on educational games, exercise, fitness and training for improvement of cardiovascular endurance (Wuest \& Bücher, 2006).

At present, the Malaysian Physical Education curriculum emphasizes education through physical activity as well as implementation of values in social and emotional development of individuals (Lumpkin, 2002; Rusli Lutan, 2001). The contribution of Physical Education quality can not only help students to become active, but can enhance thinking and confidence in addition to having a deep impact on health and life development of the child (Stirling \& Belk, 2002; Wuest \& Bücher, 2006). 


\subsection{Statement of the Problem}

The implementation of quality Physical Education curriculum affects the growth and development of students throughout their lifetime (De Vries, 2004; Hickson \& Fishburne, 2002; Siedentop, 2007). The curriculum is designed to make students active and knowledgeable through nurturing skills, values and practices in teaching and learning of fitness. This curriculum has the potential to contribute towards the growth of prosperity and development of bone and muscle, as well as stimulate the mind through social and physical activities in healthy and creative individuals (Kelly \& Melograno, 2004). However, the implementation of the curriculum as intended is not seen as something important (Corby, Halas, Dixon, Wintrup, \& Jantzen, 2005; Hardman, 2007; Olofsson, 2003). Aspects that should be adhered to by teachers based on curriculum for the purpose of teaching and learning are increasingly marginalized in many schools in the world with the existence of a significant gap between what is taught and what students should learn (Corby et al., 2005; Dismore \& Bailey, 2004; DeVries, 2004; Hardman, 2006; Hardman \& Marshall, 2000; Johns \& Dimmock, 1999; Olofsson, 2003; Wee, 2003).

\subsection{Purpose of Study}

The purpose of this study is to explore and understand phenomena in the implementation of the Physical Education curriculum among teachers in secondary schools with a focus on the role of teachers in the practice of Physical Education teaching and learning in schools.

\subsection{Conceptual Framework}

The conceptual framework underlying this study comes from the perspective of the implementation of the curriculum. Implementation of a curriculum can be described by using three approaches, namely the perspective of fidelity in the implementation or fidelity of implementation perspective, the perspective of mutual adaptation and the perspective of Enactment (Marsh \& Willis, 2007; Snyder, Bolin, \& Zumwalt, 1992). As the activities contained in Physical Education are unique (Rusli Lutan, 2001), complex and dynamic, the adaptation perspective is more dominant and is used to view the process of implementing this curriculum in schools.

The mutual adaptation perspective is aimed at describing practices in the program and involves a practical adaptation and the role played by teachers (Marsh \& Willis, 2007) with respect to the main goal desired by the curriculum developers (Berman \& McLaughlin, 1976; Leithwood \& Montgomary, 1982) in the actual implementation of the curriculum considering the reality in schools. Through this perspective, implementation of the Physical Education curriculum is viewed through three main elements, namely the type of curriculum, dimension in the curriculum, and aspects of adaptation in the implementation of the curriculum.

Types of curriculum can be categorized as a intended curriculum or what is intended, the taught curriculum or the curriculum that is taught or and the learned curriculum or what ios actually learned by students (Cuban, 1992). Intended curriculum is the curriculum that students should receive, and is formulated based on theories of teaching and learning to produce content, pedagogy or teaching methods and teaching materials appropriate to student age and ability level (Cuban, 1992; Marsh \& Willis, 2007; Schmidt et al., 1996). The taught curriculum refers to what is taught or the formal or informal teaching and learning in the classroom and in school. In the context of the study, the taught curriculum is what is taught by Physical Education teachers or the teaching and learning in the classroom. While the curriculum studied by students refers to what students get out of the teaching and learning conducted (Cuban, 1992; Marsh \& Willis, 2007; Porter, 2004; Schmidt et al., 1996).

Dimension of curriculum also can be seen through the four aspects, namely in terms of the theory held, content or curriculum materials, transfer of teaching, and learning outcomes (Leithwood \& Montgomery, 1980; Madaus \& Kellaghan, 1992; Mortimer \& Scott, 2000). However, this study focused only on the transfer of instruction by the teacher or instructional transactions of teachers as agents implementing the curriculum in schools. In the transfer of teaching, teachers are faced with three phases consisting of a chain of planning, delivery and evaluation (Darst \& Pangrazi, 2006; Mosston \& Ashworth, 2002; Orlich, Harder, Callahan, Trevisan, \& Brown, 2007).

Implementation of a program cannot avoid the negotiation process based on adaptation or naturalistic process of negotiation with respect to the main goal desired by developers for successful implementation (Berman \& McLaughlin, 1976). In this regard, Fullan (2001) has listed three major 
factors that influence success in implementing the curriculum in the schools; these are factors that require innovation, such as changes in requirements (need), clarity of purpose (clarity), complexity or difficulty (complexity) and the quality and practicality (quality and practicality) of a program; factors involving roles of local individual (local roles) involving regional, local communities, teachers and administrators, and external factors (external factors) involving the implementation of policies and plans.

\section{RESEARCH METHODOLOGY}

The purpose of the study is to explore and to understand phenomena in the implementation of the Physical Education curriculum among teachers in secondary schools with a focus on aspects of adaptation in the practice of Physical Education teaching and learning in schools. Hence, qualitative research design is most appropriate. The study conducted requires interpretive features with emphasis on understanding the phenomenon studied from the perspective of the study participants themselves. Interpretation of data was made to cover description of phenomena, analyzing data for themes or categories, and ultimately make the interpretation or conclusion about the data that give meaning to the context of the study.

\subsection{Study Site}

According to Maxwell (2005), although site selection is intended (purposeful selection) it must meet the criteria required by the researchers. The study was conducted at two secondary schools around the Klang Valley. The selected schools are SMK One and Two (pseudonym), a school that has the variety of teaching and learning facilities for Physical Education. This includes one complete school in terms of facilities such as schools that have the field, courts and one school with limited areas and facilities for teaching and learning of Physical Education. Both types of schools, namely SMK One and Two have different aspects of the area, facilities and equipment selected; this is intended to get the maximum variability. However, according to Marshall and Rossman (1999), the criteria in selecting locations include consent from the individuals who are gatekeepers or have authority to allow the study to be conducted.

\subsection{Selection of Participants}

At each site, or the school chosen, the selection of participants in the study made among individuals who could provide information that is rich and deep and are willing to give full cooperation to the researchers (Bogden \& Biklen, 2007; Maxwell, 2005). Selection of study participants was also made based on some specific criteria or criterion-based selection (Merriam, 2001) which consists of individuals who teach Physical Education and Form 1 Health, and the diversity and differences of career aspects of experience, experience courses, and professional training.

Both participants in the study are among those who teach Physical Education Form 1 which is the first study participants (P I) of School A and the second study participant (P II) from Scshool B. This was given focus because teachers have an important role in nurturing and developing students based on fitness components, skills, and sportsmanship in Physical Education syllabus towards students who have just stepped foot in the new secondary school. In an effort to know the phenomena that occur in the implementation of the Physical Education curriculum, study participants were selected among the teachers who have different aspects of career experience, experience courses, and professional training. Aspects such as career experience; exposure and participation in courses involving the game, teaching and learning, and improvement of restructuring plan in the annual levels of certain courses or seminars they have attended; and professional training from different institutions are also among the criteria desired.

\subsection{Study Period}

In qualitative research, the study period depends on the level of saturated data obtained by the state when the data collected overlap each other and do not generate new data (Bogden \& Biklen, 2007). This study was carried out simultaneously among both the study participants with a period exceeding six months.

\subsection{Data Collection Procedure}

Methods of data collection in this study involved observation, interviews, and document analysis. Using the three techniques is recommended in qualitative research as this will enhance the validity and reliability in the findings (Merriam, 2001). Appropriate to the purpose of the study, researchers 
played a role as observers to see the full implementation of the curriculum in Physical Education from the chain of planning, delivery and evaluation by separating themselves from the matter under review with the observation from a distance (as non-participant observer). Methods of data collection in observation gives researchers the opportunity to get information directly on the program, process or a thing to be studied in natural situations (Merriam, 2001).

For this study, the researcher used observation protocols that act as a guide of things to be noted in the natural background. The researcher also developed protocols for interviewing teachers and students that the question used as a guide to research and chats with participants' pupils were used for triangulation. However the interview protocol keeps changing, depending on the responses given by study participants on that day. In addition, relevant documents from the Ministry of Education, Curriculum Development Division, Department of Education Federal Territory of Kuala Lumpur and schools, have been collected and referred for study. Among them are the Syllabus, Syllabus description, teaching record book, fitness testing and assessment records and other relevant assessment, and minutes of meetings of Physical Education subject committee.

\subsection{Data Analysis}

In this study, data analysis was conducted in two stages. The first stage of analysis was during the data collection. As suggested by Glaser and Strauss (1967) in Miles and Huberman (1994), researchers using a continuous or constant comparative method comparative method in which, the data collected in consistent comparisons made from time to time. Analysis of the second stage occurs after data collection where the data is analyzed with in a more rigorous, thorough, comprehensive and systematic manner. The researcher conducted both macro and micro analysis (Straus \& Corbin, 1990) in which analysis is by understanding every line of speech in an inductive way to get an overview of the phenomenon being studied. In dealing with the occasional phenomenon involving two participants and the study carried out in the long period of time, the researcher has a lot of data and requires the appropriate software.

For this purpose, the researcher used the Nud * IST VIVO or NVivo in which the software has a high validity in helping to manage data and analyze the data collected.

All data was transcribed and exported to NVivo software to identify the open coding and then the code was developed to the next level. The term used in the software is free nodes and tree nodes. In the context of research, software is only acting in organizing data but it still relied entirely on the wisdom of researchers in giving meaning to the data obtained.

\section{RESEARCH FINDINGS}

The research findings were discussed according to the questions posed in this study regarding the Physical Education curriculum implementation among teachers in schools. Focus is given to aspects of adaptation in the practice of teaching and learning of Physical Education in school planning, delivery and evaluation.

\subsection{Planning}

Planning teaching and learning involves teachers making decisions in writing (Metzler, 2000), about the provision of a content-based syllabus, and identification of activities and materials suitable for delivering such content. Elements influencing the study participants were planning documents such as syllabus, syllabus description and annual plan; facilities and equipment in the school; experience, knowledge and skills of teachers and characteristics of students taught, including their existing knowledge (Table 1). Studies have shown that P I is in the school with complete infrastructure facilities and equipment for teaching and learning of Physical Education and he based his teaching on official documents in the planning of teaching and learning and considers the planning of teaching and learning only as formality alone (S/04 (26 / 6). In contrast, P II plans teaching and learning for the purpose of meeting the goals outlined in the syllabus. He is also considering elements of facilities and equipment and features of students in planning appropriate activities for teaching and learning. In addition, his experience, knowledge and skills makes this teacher confident in taking teh steps in meeting the goals outlined in the planning of teaching and learning of Physical Education in schools (CT/01 (22 / 7). 
Table1. Elements Influencing Planning Among Study Participants

\begin{tabular}{|l|l|l|}
\hline & P I & P II \\
\hline Official Documents (Syllabus, Description of Syllabus and Annual Plan) & $\sqrt{ }$ & $\sqrt{ }$ \\
\hline Facilities and Equipment & $\mathbf{n}$ & $\sqrt{ }$ \\
\hline Experience, Knowledge amd Skills of Teachers & & $\sqrt{ }$ \\
\hline Characteristics of Students & $\mathbf{}$ & $\sqrt{ }$ \\
\hline
\end{tabular}

Key: $(\sqrt{ })=\operatorname{consider} ;(\boldsymbol{\square})=\operatorname{did}$ not consider

\subsection{Delivery of the Physical Education Curriculum by Study Participants}

In this study, the delivery consists of two elements, namely the management and operation activities of teaching and learning. In line with the views expressed by Snyder, Bolin, and Zumwalt (1992) researchers who see the implementation of the curriculum from the perspective of adaptation are keen to know what motivates and hinders success in the implementation of a curriculum based on the intended curriculum in reality.

In the management element, research findings indicate that attitudes and responsibilities in the study participants influence their actions in dealing with students in the Physical Education. Findings (Table 2) show that P I showed less responsible attitude; the teacher ignores student discipline and mangement of classes, and does not care about the presence of students to Physical Education class. In contrast, P II showed a high responsibility in keeping up the self-image and school and he is concerned about student discipline, classroom control, and ensuring that the number of pupils who should be in the time of Physical Education is adequate. However, both study participants emphasize proper attire for students during Physical Education activities. In addition, P II also requires uniformity of dress among students while in Physical Education class.

Table2. Management Elements Considered in Implementation of Physical Education

\begin{tabular}{|l|l|l|}
\hline & P I & P II \\
\hline Student Discipline and Class Management & $\mathbf{n}$ & $\sqrt{ }$ \\
\hline Student Attendance & $\mathbf{7}$ & $\sqrt{ }$ \\
\hline Attire & $\sqrt{ }$ & $\sqrt{ }$ \\
\hline Uniformly Dressed & $\mathbf{n}$ & $\sqrt{ }$ \\
\hline
\end{tabular}

Key: $(\sqrt{ })=\operatorname{consider} ;(\boldsymbol{\square})=$ did not consider

The next element in the delivery operation is activity that includes learning the backbone and this consists of fitness, skills and sportsmanship, and practices of teaching and learning which consists of sequences and teaching strategies. For the cornerstone of learning, the findings indicate that P I only runs the game of football in six months while carrying out Physical Education, while P II carries out adaptation based on the context in which the school was faced with a shortage of facilities and infrastructure for teaching and learning, but he tried too follow the activities outlined in the Form 1 Physical Education syllabus, as seen in Table 3.

Table3. Core of Learning of Study Participants

\begin{tabular}{|l|l|l|l|l|l|l|}
\hline \multirow{2}{*}{$\begin{array}{c}\text { Study } \\
\text { Participants }\end{array}$} & \multicolumn{2}{|c|}{ Fitness } & \multicolumn{2}{c|}{ Skills } & \multicolumn{2}{c|}{ Sportsmanship } \\
\cline { 2 - 7 } & $\begin{array}{c}\text { Frequency of } \\
\text { Implementation }\end{array}$ & $\%$ & $\begin{array}{c}\text { Frequency of } \\
\text { Implementation }\end{array}$ & $\%$ & $\begin{array}{c}\text { Frequency of } \\
\text { Implementation }\end{array}$ & $\%$ \\
\hline P I & NIL & 0 & $20 / 20$ & 100 & NIL & 0 \\
\hline P II & $6 / 20$ & 30 & $11 / 20$ & 55 & $3 / 20$ & 15 \\
\hline
\end{tabular}

P I does not carry out activities specifically for fitness skills and sportsmanship strand, but he was confident, "play like this (football) it, the three strands are still there!" (S/02 (9 / 4). This makes P I ignore the basic principles of arrangement in the curriculum. The action also makes his students miss the opportunity to learn from basic phases that should be accepted to study Form 1 Physical Education. P I does not mind this, instead he uses the students as an excuse for his behavior. As he reported:

The PE students do not have examinations. If we teach, they do not care. They only want to play! They come from a flat there. To them, PE is football, football is PE is already present in the head! I once taught, but ... their hearts have reached the middle of the field. Look elsewhere ... look to next to next class la. I really do not follow them, but I understand the requirements of 
the environment. Getting such students, their Maths teacher teach they do not care, what more PE. (TB/S/02 (9/4/247-254)

The actions of P I seem to imply that he uses his students as an excuse for disregarding the core aspects of learning. He follows the rhythm of the students by allowing them to play football even though he is aware of the implications that his actions may damage the students in the long term. For $\mathrm{P}$ II, the constraints faced do not hinder him from making a direct adaptation to the teaching components. Despite the problems of having to share the place and infrastructure with another teacher, P II can still do so (CLAPPnp / CT / (25 / 3). For him, the fitness component is important and a necessary component emphasized especially in the early stages (TB/CT/01 (25 / 3). He understood this concept contains a very large component of knowledge in giving understanding to students about the activities that they do in Physical Education. Understanding the need to impart such information to students from time to time, he gives explanations in the formal classroom (CLAPPnp / CT (17 / 7).

The next element in operating activities is the implementation of teaching and learning practices of Physical Education in schools. The implementation of this aspect of the study is seen in the modifications made by participants in the Physical Education curriculum to meet demand. Through this practice, Physical Education teachers did not deviate from applying sequence aspects, namely the sequence of teaching activities, and strategies of teaching and learning (Darst \& Pangrazi, 2006). Analysis showed that study participants had different levels of rigidity in sequencing practice in teaching and learning in implementing Physical Education curriculum in schools. P I does not have teaching and practice in progressive sequence, but the opposite situation happens to P II (Table 4).

Table4. Sequence of Teaching and Learning Among Study Participants

\begin{tabular}{|l|l|l|l|}
\hline \multicolumn{1}{|c|}{ Sequence } & \multicolumn{1}{|c|}{ P I } & \multicolumn{1}{c|}{ P II } \\
\hline \multirow{3}{*}{$\begin{array}{l}\text { Sequence of Activities in Teaching } \\
\text { And Learning }\end{array}$} & Football game & Beginning & Warming up \\
\cline { 2 - 4 } & & \\
\cline { 2 - 4 } & & & Revise Previous Skills \\
\cline { 2 - 4 } & & & Statement of Objectives \\
\cline { 2 - 4 } & & Class Movement \\
\cline { 2 - 4 } & & Group Movement \\
\cline { 2 - 4 } & & End & Sinor Game \\
\cline { 2 - 4 } & & & Summary \\
\hline
\end{tabular}

The pattern of operating activities of both participants demonstrated differences in rigidity. P I only runs the game of football whereas P II has sequenced structured and progressive activities. This included elements of warm up, then repeating of skills, statement of objectives, conducting classes and movement work group, minor game and summary, as seen in the running of an explicit formula (CLAPPnp / CT / (16 / 6) at the time of teaching and learning.

\subsection{Rating and Evaluation}

Assessment of capacity which will provide an overview of students' learning ability of those who pass Physical Education as well as giving information about the effectiveness of teaching (Darst \& Pangrazi, 2006) was assessed through formative and summative assessment by study participants. Research findings indicate that P I was satisfied with evaluating students only through their involvement and participation in the Physical Education class. P II, while assessing progress based on the formative and summative assessment of three domains contained in Physical Education which includes psychomotor, cognitive and affective domain, at the same time regarded evaluation as a form of feedback rating of effort expended in the teaching and learning of Physical Education.

\section{DISCUSSION}

In this study, the Physical Education curriculum implementation by two study participants was viewed through the perspective of mutual adaptation. Researchers using this perspective tend to see things that motivate and hinder the successful implementation of a program or curriculum. In the context of the study, adaptation clearly occurred in P II in which he emphasized the quality and practicality to try to meet the distribution of time allocated to the core and component of Form 1 Physical Education teaching even though faced with constraints in the aspect of infrastructure facilities and equipment. In addition, P II emphasized quality by giving education that encompasses aspects of integration in the three objectives of psychomotor, cognitive and affective domain, content subjects, in addition to teaching and learning strategies and assessment. At the same time, this teacher 
also considers the practical aspects of teaching and learning undertaken in that the goals outlined can be achieved. Apart from that, teacher factors (local roles) responsible attitude shows itself as physical educators, have a good knowledge, commitment levels in Physical Education, and the responsible attitude towards students to ensure that they receive instruction and learning based on the syllabus makes P II perform adaptation in implementing the curriculum. Similar to the research findings by Johnson (2007), experienced and knowledgeable teachers do not face problems in making the adaptation in implementing their teaching and learning. The situation also gave him confidence that Physical Education not only plays a role in bringing excitement to the students, but plays a role in improving quality value-added of the three domains psychomotor, cognitive and affective.

A different condition operates in the case of P I where the teacher treats planning as a mere formality and does not put it in practice through the delivery of teaching and learning. The teachers also tries to meet the demand that students are only interested in playing football, and not take the opportunity to implement the curriculum as intended. Modifications to the space is very large because the status of the curriculum is not checked and P I used the game of football as a practice activity that lasted throughout the year as activity during Physical Education class.

Mutual adaptation (Berman \& McLaughlin, 1977) or adaptation (Marsh \& Willis, 2007) refers to the two-way process between curriculum developers and implementers in implementing policies to ensure success in a program. This is because outside the context of countries like the United States the described intended curriculum (intended curriculum) and curriculum documents (official documents) are two different things. A province or autonomous region has the intended curriculum than the official curriculum (Brown, 2007; Kliebard, 1992). The decentralization process allows a province or territory to apply and practice the philosophy, advantages and aspirations in achieving the desired goals (Bidwell \& Dreeben, 1992). It is different in Malaysia where practice and curriculum policy in Malaysia has made the premier curriculum or national curriculum as an official document of reference of teachers in schools. This means that the intended curriculum is also the official document that should guide the practice of teaching and learning in schools. Adaptations made by teachers in schools must meet the requirements and goals intended by the curriculum.

\section{CONCLUSION}

This study looked at the implementation of Physical Education curriculum as it happens in reality from the adaptation perspective with which this perspective tends to see things that motivate and hinder success as intended by the national curriculum. Although this study was carried out only on two teachers in the Klang Valley in Malaysia, the study findings clearly indicate that teachers play a vital role in ensuring success in implementation. The researcher hopes that this study contributes to understanding the implications and makes important suggestions for Physical Education curriculum planners to consider the appropriate proposed activities given the variations in context of the schools in the country.

\section{REFERENCES}

[1] Abu Bakar Nordin dan Ikhsan Othman. (2003). Falsafah pendidikan dan kurikulum. Tanjung Malim, Perak:Quantum Books

[2] Bailey, R. P. , \& Dismore, H.C. (2004). Sport in education (Spin Ed) Project: examining the role of physical education and sport in education. British Journal of Teaching in Physical Education, 35 (2), 7-8.

[3] Bogdan, R. C. \& Biklen, S. K. (2007). Qualitative research for education: An introduction to theory and methods (5th ed.). Boston: Allyn \& Bacon.

[4] Bucher, C. A. , \& Wuest, D. A. (2006). Foundations of physical education and sport (15th ed.). McGraw-Hill.

[5] Cameron, C., Craig, C.L., Coles, C., \& Cragg, S. (2003). Increasing physical activity through school. Encouraging physical activity through school. Ottawa, ON: Canadian Fitness and Lifestyle Research Institute Publication.

[6] Chad, K. , Humbert, M. , \& Jackson, P. (1999). The effectiveness of the Canadian quality daily physical education program on school physical education. Research Quarterly for Exercise and Sport, 70,55-64.

[7] Corby, K. D. , Hallas, J., Dixon, S., Wintrup, L. , \& Jantzen, H. (2005). Classroom teachers and the challenges of delivering quality physical education. Journal of Educational Research.Bloomington: Mar/Apr 2005. 98(4), 204-217.

[8] Cuban, L. (1992).Curriculum stability and change. Dalam P. Jackson (Ed.), Handbook of Research on Curriculum (hlm. 216-242). New York: Macmillan Publishing Company. 
[9] Cummiskey, M.D. (2007). Implementation of the Pennsylvania state standards for physical education: Teacher and student perspectives. Dissertation Abstracts International, 68(03). (ProQuest ID: 1317336701)

[10] Creswell, J. W. (2003). Research Design: Qualitative and quantitative approaches (2nd ed.). Thousand Oaks, CA: Sage Publications, Inc.

[11] Creswell, J. W. (2008). Research Design: Qualitative and quantitative approaches (3rd ed.). Thousand Oaks, CA: Sage Publications, Inc.

[12] Darling-Hammond, L ., \& Snyder, J. (1992). Curriculum studies and the traditions of inquiry: the scientific tradition. Dalam P. Jackson (Ed.), Handbook of Research on Curriculum (hlm. 41-71). New York: Macmillan Publishing Company.

[13] Deacon, B. W. (2001). British Columbia, physical education curriculum review report. Retrieved October 15,2006, from www.bced.gov.bc.ca/irp/reports/pereport.pdf.

[14] Desimone, L. (2002). How can comprehensive school reform models be successfully implemented? Review of Education Research, 72(3), 433-480.

[15] Fullan, M. (2001). The new meaning of educational change (3rd ed.). New York

[16] Hardman, K. (2006). Promise or reality? Physical education in schools in Europe Compare. Oxford:Jun 2006. 36(2), 163.

[17] Hardman, K. (2007). Current situation and prospects for physical education in the European union. Policy Department Structural and Cohesion Policies (requested by the European Parliament's committee on Culture and Education). study is available on the Internet at: Retrieved May 15, 2007, from http://www.europarl. europa. eu/activities/expert/eStudies.do?language=EN

[18] Hickson, C., \& Fishburne, G. J. (2002). Effective teaching in elementary schools: Subject area differences. Poster session at the Annual Convention of the American Alliance for Health, Physical Education, Recreation and Dance, San Diego, CA.

[19] Johns, D. P. , \& Dimmock, C. (1999). The marginalization of physical education: Improvised curriculum policy and practice in Hong Kong. Journal of Education Policy. 14(4), 363-384.

[20] Kelly, A. V. (1999). The Curriculum. Theory and practice (4th ed.). London: Sage Publications Company.

[21] Kementerian Pelajaran Malaysia.(2003). Kurikulum pendidikan jasmani di Institut/Maktab Perguruan Malaysia. Unit Kurikulum, Bahagian Pendidikan Guru.

[22] Lumpkin, A. (2002). Introduction to physical education, exercise science, and sport studies (5th ed.). McGraw-Hill.

[23] Marsh, C. J. , \& Willis, G. (2007). Curriculum: alternative approaches, ongoing issues (4th ed.). Pearson Prentice Hall.

[24] Marshall, C. , \& Rossman, G. (1999). Designing qualitative research (3rd ed.). Thousand Oaks, CA: Sage Publications, Inc.

[25] Maxwell, J. A. (2005). Qualitative research design. An interactive approach (2nded.). Sage Publications, Inc.

[26] Merriam, S. B. (2001). Qualitative research and case study applications in Education. San Francisco: Jossey-Bass Publishers

[27] Miles, M. B., \& Huberman, A. M. (1994). Qualitative data analysis: An expanded sourcebook (2nd ed.). Thousand Oaks, CA: Sage.

[28] Mosston, M. , \& Ashworth, S. (2002). Teaching physical education (5th ed.). Benjamin Cummings.

[29] National Association for Sport and Physical Education. (2001). State of the nation. Reston, VA: Author.

[30] Olofsson, E. (2003). Who needs the PE teacher? The discursive construction of the PE teacher on two different arenas. Paper presented at the European Conference on Educational Research. Hamburg

[31] Salleh Rashid. (2000). Antara angkubah sosial dan angkubah sekolah terhadap subjek PJ. Prosiding penyeli dikan ke arah inovasi dalam pedagogi. Seminar Kebangsaan Penyelidikan dan Pembangunan dalam Pendidikn 3-1 Oktober 2000.

[32] Salter, G. (1999). Unfolding attitudes and values in physical education: Streching the limits of traditional pedagogy. Journal of Teachers and Curriculum,3, 12-22.

[33] Siedentop, D. (2007). Introduction to physical education, fitness and sport (6 th ed.). McGraw-Hill.

[34] Silverman, S. , \& Subramaniam, P. R. (1999). Student attitude toward physical education and physical activity: A review of measurement issues and outcomes. Journal of Teaching in Physical Education. 19(11), 97-125.

[35] Silverman, S. , \& Subramaniam, P. R. (1999). Student attitude toward physical education and physical activity: A review of measurement issues and outcomes. Journal of Teaching in Physical Education. 19(11), 97-125. 
[36] Snyder, J., Bolin, F. , \& Zumwalt, K. (1992). Curriculum implementation. Dalam P. Jackson (Ed.),Handbook of Research on Curriculum (hlm. 402-435). New York: Macmillan Publishing Company.

[37] Strauss, A. , \& J. Corbin. (1990). Basics of qualitative research: Grounded theory procedures and techniques. Newbury Park, CA: Sage Publications, Inc.

[38] Thomas, J.L. , \& Beaudoin, C. (2002). Implementing a physical education curriculum. Two teachers experiences. Canadian Journal of Education, 27( 2), 249-268.

[39] Van Dalen, D. B. , \& Bennet, B. L. (1971). A world history of physical education (2nd ed.). NJ: Prentice Hall, Inc., Englewood Cliff.

[40] Wan Zamri Wan Muhamad. (2004). Pelaksanaan kurikulum pendidikan jasmani tingkatan empat di sekolah menengah di Kelantan. Tesis sarjana yang tidak diterbitkan. Universiti Malaya.

[41] Wee Eng Hoe. (2002). Pendidikan jasmani dan pendidikan kesihatan. Kuala Lumpur: Karisma Publications Sdn. Bhd.

[42] Wilgoose, C. E. (1979). The curriculum in physical education (3rd ed.). NJ:Prentice Hall, Inc., Englewood Cliffs.

[43] Zuber Hassan. (1999). Penilaian pelaksanaan kurikulum Pendidikan Jasmani dan kesihatan sekolahrendah. Tesis Sarjana yang tidak diterbitkan. Universiti Malaya.

[44] Zuber Hassan. (2004). A reappraisal of the physical education programme in Malaysia. Jurnal Pendidikan Guru, 17-29.

Citation: Munira Mohsin. " Adaptation Perspective in Implementing Physical Education in Schools " International Journal of Sports and Physical Education (IJSPE), vol 4, no. 2, 2018, pp. 28-36. doi:http://dx.doi.org/ 10.20431/2454-6380.0402004.

Copyright: (c) 2018 Authors. This is an open-access article distributed under the terms of the Creative Commons Attribution License, which permits unrestricted use, distribution, and reproduction in any medium, provided the original author and source are credited. 